\title{
Measurement of plasma cholinesterase activity in field workers
}

\author{
Ansam Naji Aboud Al-Haseni*, Basil Mohammed Yahya** \\ Departments of Pharmacology, Colleges of Pharmacy, \\ *Hawler Medical University, **University of Mosul
}

\section{ABSTRACT}

Received

3.10.2011
Accepted

23.11.2011

Objectives: Measurement of cholinesterase (ChE) activity is considered as an important diagnostic tool in the cases of human poisoning with organophosphate (OP) and carbamate insecticides.

Patients and methods: One hundred and seventy four subjects working in different fields and exposed to OP and carbamate compounds were conducted in this work plus fifty apparently healthy volunteers, who were neither exposed to OP and carbamate insecticides nor taken any drug during the course of this study (control group). Subjects were categorized into three groups according to the place of their work. An electrometric method was used for the measurement of blood ChE activity.

Results: The results showed significant differences at $p<0.05$ of ChE activity in the 3 groups in comparison with the control. Also the relationship between ChE activities concerning the age of the subjects and the duration of exposure in the market group was significantly different at $p<0.05$.

Conclusion: The electrometric method is simple and efficient for multiple samples and field conditions and offers a lower cost, also it is suitable for monitoring human exposure to OP and carbamate insecticides.

Key words: Cholinesterase activity, human poisoning, insecticides.

$$
\begin{aligned}
& \text { الخلاصة } \\
& \text { هاف الاراسة: بعتبر قياس نشاط خميرة الكولين استيراز مؤشر ا تشخيصيا لحالات التسمم عند الانسان في حالة }
\end{aligned}
$$

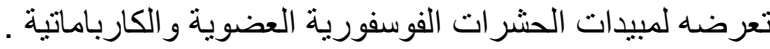

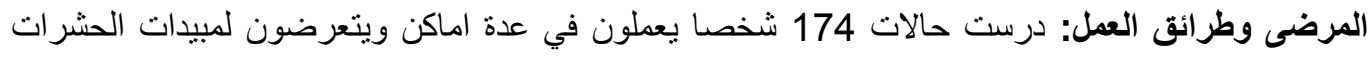

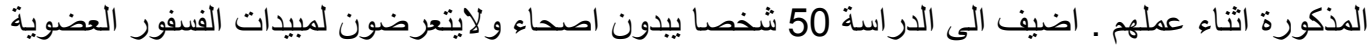

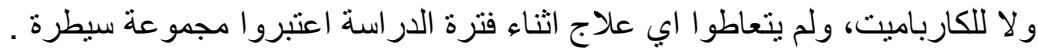

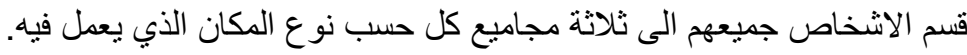

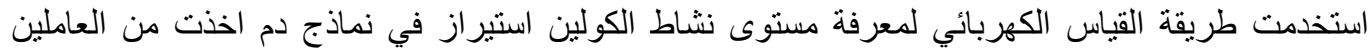

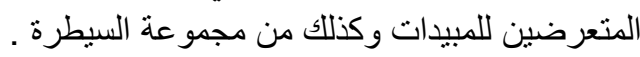

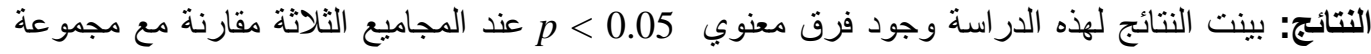

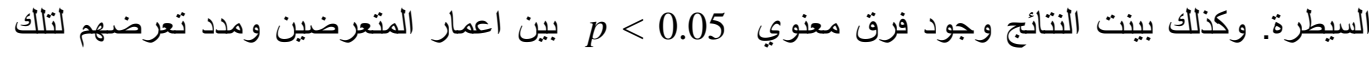

$$
\begin{aligned}
& \text { المبيدات للدى مجموعة العاملين في السوق. } \\
& \text { العضوية و الكارباماتية بشكل فاعل . }
\end{aligned}
$$


M easurement of blood cholinesterase (ChE) activity is considered to be an ideal biomarker for monitoring exposure and diagnosis of poisoning with ChE inhibitors ${ }^{1,2}$.

Cholinesterase is inhibited due to exposure to organophosphate (OP) and carbamate insecticides ${ }^{3}$. This inhibition prevents the destruction of acetylcholine (Ach) leading to its accumulation at the receptor sites (both nicotinic and muscarinic) ${ }^{4}$. The action of carbamate insecticides is similar to that of OP, but inhibits the AChE reversibly, continuous inhibition of ChE express the level of intoxication in the people exposed to OP and carbamate insecticides ${ }^{5}$.

The electrometric method of Mohammad et al. ${ }^{6,7}$ was used for measurement of blood ChE activity, and the percentage of ChE inhibition in human blood samples is compared with control blood samples taken from non exposed individuals to these compounds (apparently healthy subjects). All subjects in this study except the control dealt with OP and carbamate insecticides and varied in the way of exposure according to the time consumed in the work and the nature of work place.

The purpose of this study was to examine the degree of inhibition of ChE activity in subjects exposed to ChE inhibitors by inhalation, skin contact and sometime; through ingestion of contaminated food in markets, agricultural fields, and veterinary clinics.

\section{Subjects and methods}

One hundred and seventy four subjects working in fields and exposed to OP and carbamate compounds were recruited in this work. A control group of 50 apparently healthy volunteers from Erbil city were also included, their ages were $31 \pm 9.79$ years, they were neither exposed to anticholinesterases nor taken any drug during the course of this study.

Subjects were categorized into 3 groups. The first group included 31 individuals the mean of their ages was $38 \pm 13.12$ years, who were working in market shops selling pesticides, and they were exposed to anticholinesterases during mixing, preparing, handling and by inhalation and dermal contact. The duration of exposure was $15.3 \pm 0.69$ years. The second group included 67 individuals, the mean of their ages was $47 \pm 0.86$, who were working in agricultural fields in different sites of Erbil city and surrounding villages, and exposed to anticholinesterases by inhalation and dermal contact during spraying, mixing and handling of these compounds. The duration of exposure was $19.1 \pm 9.03$ years. The third group included 76 individuals the mean of their age was $42 \pm 12.40$ years, some were working in veterinary clinics at different sites of Hawler Province, and exposed to anticholinesterase compounds by inhalation and dermal contact, during mixing, handling, sheep dipping with these compounds in Baharka, Ashwka, Bansellawa, Kawshtaba, Enkawa and Bastura villages. The mean of years of exposure was $16 \pm 9.03$ years.

Venous blood samples $(2-5 \mathrm{ml})$ were obtained from the subjects and transferred into dry clean test tubes containing anticoagulant (EDTA). 
Blood samples were immediately kept in an ice bath; plasma was separated by centrifugation at $3000 \mathrm{rpm}$ for $15 \mathrm{~min}$, then transferred into dry clean test tube and placed in ice bath until its use for assay during the next two days. Cholinesterase activity was measured by the modified electrometric method of Mohammad et $\mathrm{al}^{7,8}$.

Duncan-test was used to compare ChE activity among worker groups and control $^{9}$.

\section{Results}

Plasma ChE activities in market group who dealt with and exposed to insecticides were significantly below ChE activities of the control group, veterinarians and agricultural groups as shown in Table 1.
The agricultural group showed plasma ChE activities significantly below ChE activities in the control group, and there was no significant difference between this group and veterinary group (Table 1).

Also plasma ChE activities in veterinary group were significantly below ChE activities in the control group, and there was no significant difference between this group and agricultural group (Table 1).

The relationship between ChE activities and duration of exposure in market group showed a significant correlation. However, the relationship between ChE activities and duration of exposure in agricultural and veterinary groups showed no significant correlation between ChE activities and duration of exposure (Table 2).

Table 1. Plasma cholinesterase activities in normal (control), market, agricultural and veterinarians

\begin{tabular}{|l|l|l|l|l|}
\hline $\begin{array}{l}\text { Groups } \\
\text { Parameter }\end{array}$ & $\begin{array}{l}\text { Controls } \\
(\mathrm{N}=50)\end{array}$ & $\begin{array}{l}\text { Market group } \\
(\mathrm{N}=31)\end{array}$ & $\begin{array}{l}\text { Agricultural } \\
\text { group } \\
(\mathrm{N}=67)\end{array}$ & $\begin{array}{l}\text { Veterinary } \\
\text { group } \\
(\mathrm{N}=76)\end{array}$ \\
\hline $\begin{array}{l}\text { ChE Activity } \\
(\Delta \mathrm{pH} / 30 \mathrm{~min})\end{array}$ & $0.93 \pm 0.04^{\mathrm{a}}$ & $0.74 \pm 0.07^{\mathrm{b}}$ & $0.83 \pm 0.07^{\mathrm{c}}$ & $0.84 \pm 0.07^{\mathrm{c}}$ \\
\hline
\end{tabular}

Different letters represent significant difference at $p<0.05$

Table 2. The relationship between plasma ChE activities, age, and duration of exposure to insecticides in market, agricultural and veterinarian groups

\begin{tabular}{|l|l|l|l|l|}
\hline $\begin{array}{l}\text { Groups } \\
\text { Parameter }\end{array}$ & $\begin{array}{l}\text { Controls } \\
(\mathrm{N}=50)\end{array}$ & $\begin{array}{l}\text { Market group } \\
(\mathrm{N}=31)\end{array}$ & $\begin{array}{l}\text { Agricultural } \\
\text { group } \\
(\mathrm{N}=67)\end{array}$ & $\begin{array}{l}\text { Veterinary } \\
\text { group } \\
(\mathrm{N}=76)\end{array}$ \\
\hline $\begin{array}{l}\text { ChE Activity } \\
(\Delta \mathrm{pH} / 30 \mathrm{~min})\end{array}$ & $0.93 \pm 0.04$ & $0.74 \pm 0.07$ & $0.83 \pm 0.07$ & $0.84 \pm 0.07$ \\
\hline Age-year & $31.5 \pm 09.79$ & $38.0 \pm 13.22$ & $47.3 \pm 08.62$ & $42.1 \pm 12.40$ \\
\hline $\begin{array}{l}\text { Duration of } \\
\text { exposure (year) }\end{array}$ & ----- & $15.3 \pm 06.92 *$ & $19.13 \pm 09.03$ & $16.0 \pm 10.91$ \\
\hline
\end{tabular}

* Denote a statistically significant difference at $p<0.05$ 


\section{Discussion}

Determination of ChE activity in the blood and monitoring the signs of intoxication is a basic method for diagnosis of intoxication with OPs and carbamates $^{10,11,12}$.

Plasma cholinesterase provides a more sensitive indicator of OP toxicity, and it is considered a simple mean for detecting subchronic or chronic OP exposure $^{13,14}$. The modified electrometric method is simple, rapid and efficient for multiple samples and field conditions and offers a lower cost also it is suitable for monitoring exposure to OPs and carbamate insecticides ${ }^{15}$.

The present study demonstrated that human exposure to ChE inhibitor at their work place among veterinary clinics, agricultural fields and in pesticides selling stores showed a significant decrease in ChE activity, especially in those who work in market. This is because those people exposed to a wide variety of ChE inhibitors for along time by inhalation and polluted air, mostly in closed place, by dermal contact and probably from contaminated food and drink by these compounds in their shops ${ }^{16}$.

This results are in consistent with the finding of Petrianu and Lotti ${ }^{17,18}$, who found that ChE enzyme inhibited in human exposed to ChE inhibitors at the work place. Also, other workers ${ }^{19}$ found that occupational exposure to most OPs caused poisoning by the same mechanism of action. Others reported that farm workers who exposed to low-level chronic OPs pesticides, showed neurobehavioral impairment ${ }^{19}$.
Our result was not in agreement with Eddieston et al. ${ }^{20}$, who found that the variability in toxic effect is unlikely to be due to difference between patients, but due to formulation of OPs. Here a significant correlation between ChE activity and duration of exposure for market group, due to continuous exposure for long time, mostly in a close place and by different routes of exposure, cause decrease in ChE activity $^{18}$, Mileson et al. and Arcury et al. ${ }^{21}$ mentioned additional factor for toxicity with ChE enzyme inhibitors are food intake, water drinking, and contaminated clothes, sometime gloves also in close place. Most workers think that these chemicals are not dangerous to human, but they only hurt insects and weeds. The same opinion was given by and Wesseling et $\mathrm{al}^{21}$ who mentioned that some workers of farm work have no idea about the harmful effect of the chemical and have no regard for their health.

This study showed no significant correlation between duration of exposure and plasma ChE activity for agricultural and veterinary groups as in table 2, this is because the workers in these groups were not exposed to ChE inhibitor continuously.

But the worker in close place (shops and stores), had low ChE activity. The results are in agreement with Vidyasagar et $\mathrm{al}^{22}$, who found a progressive fall in both $\mathrm{RBC}$ and plasma ChE level which correlated with the severity of poisoning. Furthermore, Karmer et $\mathrm{al}^{23}$, demonstrated that, absorption through the skin has been identified as a major route for occupational exposure to $\mathrm{OP}$ 
insecticides and repeated dermal exposure increase its toxicity through accumulation and prolonged redistribution from skin. While Arcury et $\mathrm{al}^{21}$, reported that the skin acts as a barrier to exposure rather than as a permeable membrane, through which pesticides can absorbed.

Karmer et al. $^{23}$ reported that repeated long term exposures to $\mathrm{OP}$ pesticides and carbamates decrease the blood ChE activity without clinical manifestation. This is due to tolerance to cholinergic over stimulation after repeated exposure, but the decrease in ChE activity depend on the severity of poisoning, where Gard and Hooper ${ }^{24}$ found that ChE activity decreased with age. Age did not appear to have an effect on activity of ChE enzyme. This finding correlates with those reported by $\mathrm{Ahmed}^{25}$. In Conclusion, the modified electrometric method is simple, rapid, and efficient method in measuring ChE activities in workers after exposure to OPs and carbamate and the exposure to these compounds in close place with poor ventilation decrease ChE activities. Also long term exposure (chronic exposure) to OPs and carbamate depresses $\mathrm{ChE}$ activities more than those caused by shorter durations.

\section{References}

1- Portmann R, Brodbeck U, Gentinetta R. Evaluation of methods for interlaboratory comparison tests on measurements of cholinesterase activity. The sixth meeting in the CBMTS, Switzerland, 7-12 May 2000.

2- Patil J.A Patil AJ, Govindwar SP. Biochemical effects of various pesticides on sprayers of grape gardens, Ind $\mathrm{J}$ Clin Biochem 2003;18(2):16-22.

3- Slotkin TA, Levin ED, Seidler FJ. Comparative developmental neurotoxicity of organophosphate insecticides: effects on brain development are separable from systemic toxicity, Environ Health Persp 2006;114:746-51.

4- Moretto A, Experimental and clinicial toxicology of anticholinesterase. Toxical Lett 1998;102-103:509-13.

5- Klaassen CD. Casarett and Doull's Toxicology-The Basic Science of Poisons, $6^{\text {th }}$ edition, 2001, McGraw-Hill, New York, 1235P.

6- Mohammad F.K, Simple electrometric method for determination of blood and tissue cholinesterase activities in man and animals: Implications for environmental biomonitoring, Internet J Toxicol, Vol. 2005; No. 2.

7- Mohammad FK, Al-Baggou BK, Alias AS, Faris GAM. Application of an electrometric method for measurement of in vitro inhibition of blood cholinesterases from sheep, goats, and cattle by dichlorvos and carbaryl, Vetern Med 2006;51(2):45-50.

8- Mohammad F.K, Faris G.A.M and Al-Kassim NA, A modified electrometric method for measurement of erythrocyte acetylcholineesterase activity in sheep, Vet Hum Toxicol 1997;36:337-9.

9- Jones D, Pharmaceutical statistics, $8^{\text {th }}$ edition, B, Pharmaceutical Press, London, Jolliffe I.T and 
Garthwaite P.H, Statistical inference, $2^{\text {nd }}$ edition, Oxford University Press, 2002; 352P.

10- Reiner E, Sinko G, SkrinjaricSpoljar M, Simeon-Rudolf V.Comparison of protocols for measuring of human blood cholinesterases by the Ellman method. Arh Hig Rada Toksi 2000;51:13-8.

11- Bajgar J, Laboratory diagnosis of organophosphates-nerve agent poisoning. Klin Biochem Metab 2005;13(1):40-47.

12- Wilson BW, McCurdy S.A, Henderson JD, McCarthy SA and Billitti JE, Structure and function of Cholinesterase and related proteins, Plenum Bub, NY, 1998, P 539-46.

13- Mortensen S.R, Brimijoin S, hooper MJ and Padilla S, Comparison of the in vitro sensitivity of rat acetylcholinesterase to chlorpyrifos-oxon: what do tissue IC50 values represent? Toxicol. Appl Pharmacol 1998,148,46-9.

14- Saskatchewan L, Pesticide Safety Handbook, Regional Saskatchewan agriculture and agriculture food office, June 27-2007.

15- Ahmed O.A H and Mohammad F.K, A simplified electrometric technique for rapid measurement of human blood cholinesterase activity. Inter J Toxicol 2005, 2(1):1-13.

16- Reigart JR andRoberts J.R, Recognition and management of pesticide poisonings, $5^{\text {th }}$ Edition, US Environmental Protection Agency 1999, 2750P.
17- Petroianu GA, Poisoning with organophosphorus compounds (OPC), Mythology vs reality, Middle East J Emerg Med 2006; Vol 6, No 1.

18- Lotti M, Cholinesterase inhibition: complexities in interpretation. Clin Chem 1995,41(12):1814-8.

19- Joshi S.K, Pesticides poisoning in Nepal, Kathma. Uni Med J 2003;1(3):157-7.

20- Eddleston M, Eye P, Worek F, E, Hittarage A, Azhar S, Dissanayake $W$, Sheriff $M$, et al.Differences between organophorus insecticides in human self-poisoning: a prospective cohort study. Lancet 2005;366:1452-9.

21- Arcury T.A, Quandt SA, Rao P and Russell GB, Farmworker pesticide exposure perceptions and beliefs: using cultural knowledge to improve safety education, "Pesticide Exposure and Health", SOEH Conference, 9 July 2002.

22- Vidyasagar J, Karunakar N, Reddy MS, et al. Oxidative stress and antioxidant status in acute organophosphorous insecticide poisoning. Indian $\mathrm{J}$ Pharm 2004;36(2):76-9.

23- Kramer RE, Wellman SE, Zhu H, et al. A comparison of cholinesterase activity after intravenous, oral or dermal administration of methyl parathion, J Biomed Sci 2002, 9:140-148.

24- Gard NW, Hooper MJ. An assessment of potential hazards of pesticides and environmental contaminants, P: 294-310. In: Ecology and management of neotropical migratory birds, $\mathrm{T}$ 
Martin and Finch D editors, Oxford university Press 1995.

25- Ahmed $\mathrm{OAH}$ Modification and application of an electrometric cholinesterase method for monitoring exposure to organophosphate and carbamate insecticides, M.Sc Thesis, College of Pharmacy, Mosul, 84P 2001. 